\title{
Mesophotic reef fish assemblages of the remote St. Peter and St. Paul's Archipelago, Mid-Atlantic Ridge, Brazil
}

\author{
Marcos Rogerio Rosa ${ }^{1}$ Aline Cristina Alves ${ }^{2} \cdot$ Diego Valverde Medeiros $^{3} \cdot$ \\ Ericka Oliveira Cavalcanti Coni ${ }^{4} \cdot$ Camilo Moitinho Ferreira $^{4} \cdot$ Beatrice Padovani Ferreira $^{5}$. \\ Ricardo de Souza Rosa ${ }^{6}$ - Gilberto Menezes Amado-Filho ${ }^{7}$ Guilherme Henrique Pereira-Filho ${ }^{8}$. \\ Rodrigo Leão de Moura ${ }^{9}$ Fabiano Lopes Thompson' ${ }^{9}$ Paulo Yukio Gomes Sumida ${ }^{10}$. \\ Ronaldo Bastos Francini-Filho ${ }^{11}$
}

Received: 4 February 2015/Accepted: 9 October 2015/Published online: 15 October 2015

(C) Springer-Verlag Berlin Heidelberg 2015

\begin{abstract}
Mesophotic reef fish assemblages (30-90 m depth) of the small and remote St. Peter and St. Paul's Archipelago (SPSPA), Mid-Atlantic Ridge, Brazil, were characterized using remotely operated vehicles. Ordination analyses identified distinct fish assemblages in the upper $(30-50 \mathrm{~m})$ and lower $(50-90 \mathrm{~m})$ mesophotic zones, the former characterized by high abundances of species that are also abundant at euphotic reefs (Caranx lugubris, Melichthys niger, Stegastes sanctipauli and Chromis multilineata) and the latter dominated by two mesophotic specialists (Prognathodes obliquus and Chromis enchrysura). Planktivores dominated fish assemblages, particularly in the upper mesophotic zone, possibly due to a
\end{abstract}

Communicated by Biology Editor Dr. Andrew Hoey

Ronaldo Bastos Francini-Filho

rbfrancinifilho@gmail.com

1 Programa de Pós-Graduação em Oceanografia Biológica, Instituto Oceanográfico, Universidade de São Paulo, São Paulo, SP 05508-120, Brazil

2 Programa de Pós-Graduação em Ciências Biológicas (Zoologia), Universidade Federal da Paraíba, João Pessoa, PB 58059-900, Brazil

3 Programa de Pós-Graduação em Ecologia e Monitoramento Ambiental, Universidade Federal da Paraíba, Rio Tinto, PB 58297-000, Brazil

4 Programa de Pós-Graduação em Ecologia e Conservação, Universidade Estadual da Paraíba, Campina Grande, PB 58109-753, Brazil

5 Departamento de Oceanografia, Centro de Tecnologia e Geociências, Universidade Federal de Pernambuco, Recife, PE 50670-901, Brazil

6 Departamento de Sistemática e Ecologia, Centro de Ciências Exatas e da Natureza, Universidade Federal da Paraíba, João Pessoa, PB 58051-900, Brazil greater availability of zooplankton coming from the colder Equatorial Undercurrent in mesophotic depths of the SPSPA. Turf algae, fleshy macroalgae and scleractinian corals dominated benthic assemblages between 30 and $40 \mathrm{~m}$ depth, while bryozoans, black corals and sponges dominated between 40 and $90 \mathrm{~m}$ depth. Canonical correspondence analysis explained $74 \%$ of the relationship between environmental characteristics (depth, benthic cover and complexity) and structure of fish assemblages, with depth as the most important independent variable. Juveniles of Bodianus insularis and adults of $P$. obliquus and $C$. enchrysura were clearly associated with branching black corals (Tanacetipathes spp.), suggesting that black corals play key ecological roles in lower mesophotic reefs

7 Instituto de Pesquisas Jardim Botânico do Rio de Janeiro, Rio de Janeiro, RJ, Brazil

8 Instituto do Mar, Universidade Federal de São Paulo, Campus Baixada Santista, Santos, SP 11030-400, Brazil

9 Instituto de Biologia and SAGE/COPPE, Universidade Federal do Rio de Janeiro, Rio de Janeiro, RJ 21944-970, Brazil

10 Departamento de Oceanografia Biológica, Instituto Oceanográfico, Universidade de São Paulo, São Paulo, SP 05508-120, Brazil

11 Departamento de Engenharia e Meio Ambiente, Universidade Federal da Paraíba, Rio Tinto, PB 58297-000, Brazil 
of the SPSPA. Results from this study add to the global database about mesophotic reef ecosystems (MREs) and provide a baseline for future evaluations of possible anthropogenic and natural disturbances on MREs of the SPSPA.

Keywords Black corals - Bodianus insularis . Mesophotic reefs · Oceanic islands · Prognathodes obliquus $\cdot$ Stegastes sanctipauli

\section{Introduction}

The Atlantic coast of Brazil and its oceanic islands are partially isolated from the Caribbean by the Amazon River outflow and from the west coast of Africa by the wide expanse of the Atlantic (Rocha 2003; Floeter et al. 2008). Such geographical isolation leads to relatively high endemism of reef fish (ca. $25 \%$ ) and to the classification of the region as the "Brazilian Province" (Floeter et al. 2008). The Brazilian oceanic insular reef fish fauna is an impoverished outpost of the Brazilian Province, encompassing ca. 260 species. The lowest insular endemism (5\%) in Brazil is recorded for the Fernando de Noronha Ridge (Fernando de Noronha Archipelago plus Rocas Atoll), an intermediate level $(5.7 \%)$ for the Trindade/Martim Vaz Insular group and the highest insular endemism (9\%) for the St. Peter and St. Paul's Archipelago (SPSPA) (Floeter and Gasparini 2000; Floeter et al. 2008).

Quantitative information on the structure of euphotic reef fish assemblages $(0-30 \mathrm{~m}$ depth) is now available for the four Brazilian oceanic sites: Fernando de Noronha Archipelago (Minte-Vera et al. 2008; Krajewski and Floeter 2011), Rocas Atoll (Rosa and Moura 1997; Longo et al. 2015), the SPSPA (Luiz et al. 2015) and the Trindade/ Martim Vaz Island group (Pereira-Filho et al. 2011; Pinheiro et al. 2011). Euphotic reefs of the SPSPA harbor an impoverished reef fish fauna in comparison with mainland and other larger Brazilian oceanic islands (Luiz et al. 2015), including four recognized endemic reef fish species (Choranthias salmopunctatus, Prognathodes obliquus, Enneanectes smithi and Stegastes sanctipauli) (Lubbock and Edwards 1981; Feitoza et al. 2003; Ferreira et al. 2009; Anderson and Heemstra 2012). The SPSPA is an important site for pelagic fisheries (Vaske-Jr et al. 2006; Hazin et al. 2009), and there is evidence for overfishing in the area despite its isolation (Ferreira et al. 2009). Overfishing is believed to have caused the local population extinction of the Galapagos shark Carcharhinus galapagensis and sharp decreases in the abundance of other shark species (Luiz and Edwards 2011).

Mesophotic reef ecosystems (MREs) occur in tropical and subtropical regions in depths ranging between 30 and
$150 \mathrm{~m}$. They are considered as extensions of shallow reef communities, but at the same time harbor unique biodiversity and ecological characteristics (Hinderstein et al. 2010; Harris et al. 2013; Kane et al. 2014). Although MREs are not immune to local and global disturbances (Bak et al. 2005; Menza et al. 2007; Lesser and Slattery 2011), they may be less susceptible than shallow and highly threatened reefs, thus possibly functioning as refuges (the "deep reef refugia" hypothesis; Lesser et al. 2009; Bongaerts et al. 2010). Despite their importance, MREs remain poorly studied due to logistical challenges, with gaps in knowledge of community composition, depth range of taxa and other basic biological and ecological aspects (Lesser et al. 2009; Kahng et al. 2010, 2014). Until recently, there were few studies focusing on southwest Atlantic MREs, with the exceptions of one for the northeast Brazilian coast (Feitoza et al. 2005) and another for the Trindade/Martim Vaz Island group (Pereira-Filho et al. 2011). More recently, three other studies have been published: one focusing on benthic assemblages of the euphotic ( $0-30 \mathrm{~m}$ depth) and the upper mesophotic $(30-60 \mathrm{~m})$ zones of the SPSPA (Magalhães et al. 2015); a study assessing microbial, benthic and fish assemblages of mesophotic reefs of the Vitória-Trindade seamount chain (VTC; Meirelles et al. 2015); and an analysis of the fish biodiversity associated with the VTC (Pinheiro et al. 2015).

This study provides the first quantitative assessment of mesophotic reef fish assemblages of the SPSPA. Sampling was performed at 30-90 m depth, with the following main goals: (1) to describe depth variation in abundance and trophic structure of fish assemblages; (2) to evaluate the relative influence of depth, benthic cover and complexity on the structure of fish assemblages; and (3) to discuss the similarities/differences between mesophotic reef fish assemblages of the SPSPA and those from other locations in the Atlantic and other geographical regions.

\section{Materials and methods}

\section{Study area}

The SPSPA is a small group of five islets and rocks (total emerged area $\sim 15,000 \mathrm{~m}^{2}$ ) located in the central equatorial Atlantic Ocean, just above the Mid-Atlantic Ridge and about $1000 \mathrm{~km}$ off the northeastern Brazilian coast (Fig. 1) (Edwards and Lubbock 1983a, b; Feitoza et al. 2003). The SPSPA is influenced by the surface South Equatorial Current, which flows westwards, as well as by the Equatorial Undercurrent, which flows eastwards below the surface, at depths of $40-150 \mathrm{~m}$. The area of reefs $<100 \mathrm{~m}$ depth is about $0.5 \mathrm{~km}^{2}$ (Edwards and Lubbock 1983a, b). Shallow rocky reefs of the SPSPA are covered mainly by 
a

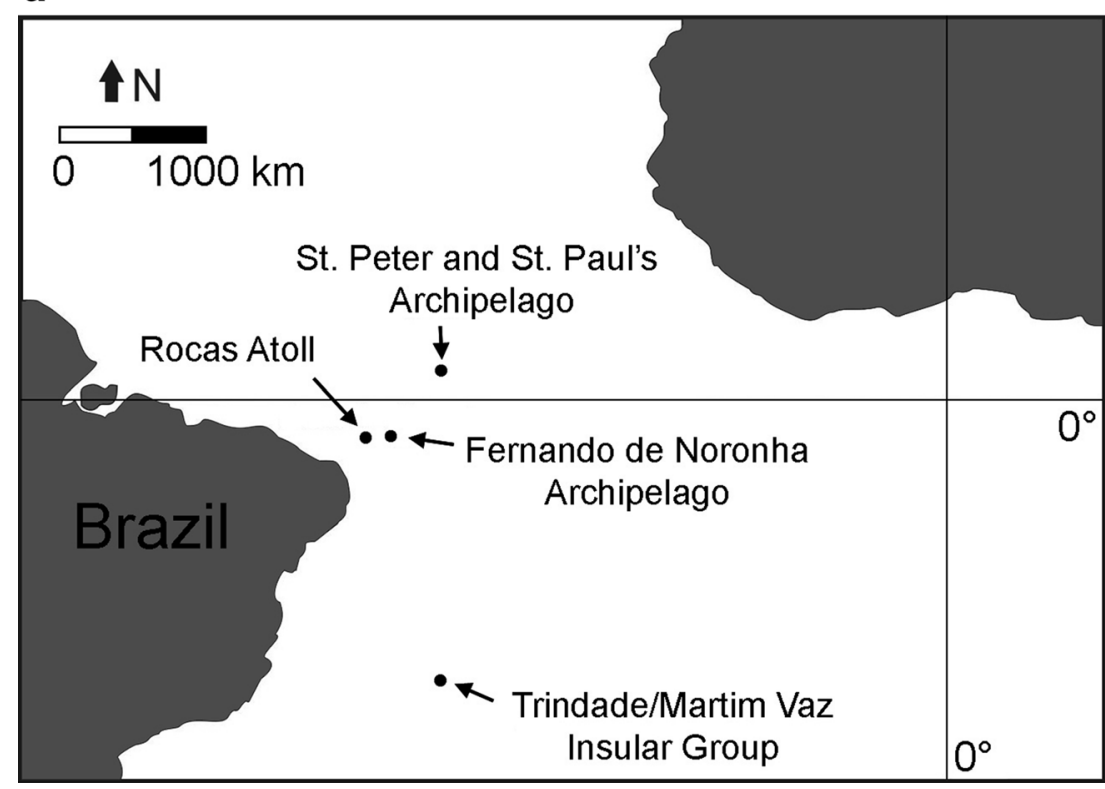

b

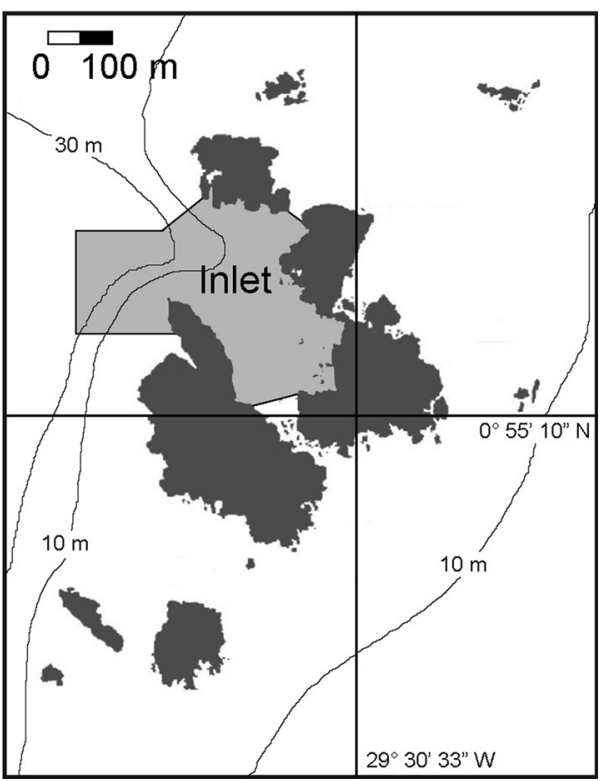

Fig. 1 Map showing: a location of the St. Peter and St. Paul's Archipelago (SPSPA) and other Brazilian oceanic islands in the South Atlantic Ocean and $\mathbf{b}$ detail of the SPSPA showing the study area (light gray)

the zoanthid Palythoa caribaeorum and algae of the genera Bryopsis, Caulerpa and Dictyota. In depths $>30 \mathrm{~m}$, the most common organisms are the scleractinian corals Madracis decactis and Scolymia wellsi, crustose calcareous algae and bryozoans. Sponges and branching black corals of the genus Tanacetipathes are dominant in depths $>40 \mathrm{~m}$ (Edwards and Lubbock 1983a, b; Magalhães et al. 2015).

\section{Sampling procedures}

Sampling was performed during four expeditions between September 2010 and June 2011, totaling $60 \mathrm{~d}$ of fieldwork. Fish and benthic assemblages were assessed using video footage obtained using two remote-operated vehicles (ROV; VideoRay Explorer and Seabotix LBV150S2, both equipped with light and laser scale). Samples were composed of $5 \mathrm{~min}$ continuous footage covering a circular area with $\sim 4 \mathrm{~m}$ radius. The ROV was maintained as stationary as possible in the center of each sampling unit, and a full rotation was performed for counting fish species. A total of 46 samples were obtained across a 30-90 $\mathrm{m}$ depth gradient, with the following sampling sizes per $10 \mathrm{~m}$ depth stratum: $30-40 \mathrm{~m} \quad(n=18)$, 40-50 m $(n=11), 50-60 \mathrm{~m}(n=6), 60-70 \mathrm{~m}(n=5)$, $70-80 \mathrm{~m}(n=3), 80-90 \mathrm{~m}(n=3)$.

Relative cover of benthic organisms was quantified from 30 still frames per ROV sample (i.e., one frame every $10 \mathrm{~s}$ ). Images were taken about $50 \mathrm{~cm}$ from the bottom and as perpendicular to the substrate as possible. The Coral Point Count with Excel extensions (CPCe) software was used for image analysis (Kohler and Gill 2006), with ten randomly distributed points used per frame (totaling 300 points per sample unit). The following categories were used in the benthic cover characterizations: bare rock; branching black corals (Tanacetipathes spp.); Caulerpa spp.; crustose calcareous algae; fleshy macroalgae (other than Caulerpa spp.); bryozoans; hydrozoans; live scleractinian corals; sediment; sponges; turf algae; and zoanthids. General habitat features recorded here were similar to those previously recorded for the SPSPA (Edwards and Lubbock 1983b), and a comprehensive analysis with greater taxonomic resolution is given by Magalhães et al. (2015).

Benthic complexity was visually estimated from ROV video samples by assigning values from 1 to 3 to each frame (i.e., 15 measurements per sample). Samples with no crevices and a smooth surface received a value of 1 ; samples with few crevices and small rocks received a value of 2 ; samples containing many crevices and rocks, as well as three-dimensional organisms (e.g., branching sponges and black corals), received a value of 3 . Results obtained may be considered as a reliable metric considering the gross resolution applied (Wilson et al. 2007).

Preliminary sampling revealed that juveniles of Bodianus insularis and the two mesophotic specialists, Chromis enchrysura and Prognathes obliquus, were clearly associated with branching black corals in the mesophotic zone. Thus, the absolute number of black coral colonies per sample, as well as the identity and abundance of fishes within branches of each colony, was recorded. 
Due to logistical limitations with operation of the ROVs, only one site on the northeast coast of the SPSPA was sampled. The northeast portion of the archipelago is almost permanently sheltered from the strong waves and currents that act in the other portions of the SPSPA. Despite the lack of site replication, the small area of the SPSPA allowed for the assessment of about $15 \%$ of the total perimeter of the archipelago (see Fig. 1).

\section{Data analyses}

Quantitative analyses used data for species with $\geq 0.1 \%$ of total fish abundance and frequency of occurrence in more than five samples (except for the analyses of trophic groups, for which all species were taken into account). The 12 species retained for analyses belong to seven families and represented $97.4 \%$ of total fish abundance recorded. Fish species were classified according to their predominant diet in one of the following trophic categories: omnivores; piscivores; predators on benthic invertebrates; or territorial herbivores (Feitoza et al. 2003; Francini-Filho and Moura 2008; Krajewski and Floeter 2011; Pinheiro et al. 2011, Luiz et al. 2015) (Table 1).

Non-metric multidimensional scaling (MDS) ordination was used to summarize spatial similarities (Bray-Curtis) according to benthic cover and fish abundance. Analyses of similarities (ANOSIM) were applied to evaluate possible significant differences between depth strata. Linear correlations (Spearman) were used to investigate the relationship between benthic cover/fish abundance and the MDS axes. Only categories/species with correlation $>0.3$ were included in the final solution, and results were illustrated as superimposed vectors in the MDS diagrams (Clarke and Warwick 1994).

The relationship between depth and abundance of the 12 most abundant fish species (see Table 1) was explored using generalized additive models (GAM). Models were built using the Gaussian distribution, an identity link and cubic regression splines (Hastie and Tibshirani 1990). Variance explained by each model (pseudo-r-squared) was estimated as $1-$ (residual deviance/null deviance) (Swartzman et al. 1992).

Canonical correspondence analysis (CCA) (ter Braak 1996) was used to evaluate the relative influence of habitat characteristics (depth, benthic cover and complexity) on the structure of fish assemblages. A forward selection procedure was used to include only the most important independent variables, i.e., those that increased the explanatory power of the model. Only significant variables, as defined by a Monte Carlo permutation test (999 permutations), were included in the final solution.

All analyses were carried out in $\mathrm{R}$ (version 3.1.2; R Core Development Team 2014; available at http://www.R-pro ject.org).

\section{Results}

A total of 19 species belonging to 12 families were recorded $(\sim 35 \%$ of the reef fish species pool known for the SPSPA) (Feitoza et al. 2003; Floeter et al. 2008; Luiz et al. 2015). The five most abundant species were Chromis multilineata (29.0\% of total fish abundance), Melichthys niger (24.3\%), Caranx lugubris (19.5\%), Stegastes sanctipauli $(7.8 \%)$ and P. obliquus $(3.1 \%)$ (Table 1$)$. The two-dimensional MDS ordination diagram and ANOSIM (Global $R=0.52, p=0.01$ ) showed that distinct fish assemblages were associated with two different zones (i.e., no differences between depth strata within each zone): one at 30-50 m depth and another at 50-90 m depth, hereafter called upper (UMZ) and lower (LMZ) mesophotic zones, respectively. Most typical species of the UMZ (highest values of Spearman correlation considering the first two axes of the MDS) were C. lugubris (0.61), M. niger (0.57), S. sanctipauli (0.45) and Chromis multilineata (0.37), while the most typical species of the LMZ were $P$. obliquus (-0.72) and C. enchrysura (-0.68) (Fig. 2a).

Fish abundance varied significantly by depth for seven species. Bodianus insularis, C. multilineata, Halichoeres radiatus, $M$. niger and $S$. sanctipauli showed the highest abundances in the UMZ (Fig. 3c, f, g, i, 1). Chromis enchrysura and $P$. obliquus were nearly absent from the UMZ and increased sharply in abundance from $60 \mathrm{~m}$ depth onwards (Fig. 3e, k). Twenty individuals of B. insularis (35.2\% of total number of individuals recorded for this species) were $<20 \mathrm{~cm}$ total length (TL), all of them restricted to depths between 40 and $70 \mathrm{~m}$ depth.

Planktivores dominated mesophotic fish assemblages (33.1\% of total fish abundance), followed by omnivores (29.6\%), piscivores $(20.6 \%)$, predators on benthic invertebrates $(9.0 \%)$ and territorial herbivores $(7.8 \%)$. The abundance of predators on benthic invertebrates increased sharply from $50 \mathrm{~m}$ depth onwards (Fig. 4a), a pattern largely driven by a single species ( $P$. obliquus). Abundance of omnivores, planktivores and territorial herbivores was highest in the UMZ (Fig. 4b, d, e). No significant trend in abundance according to depth was recorded for piscivores (Fig. 4c).

The two-dimensional MDS ordination diagram and ANOSIM (Global $R=0.65, p=0.01$ ) identified three distinct benthic assemblages associated with the following depth strata: 30-40 m (dominated by Caulerpa spp., other fleshy macroalgae, scleractinians and turf algae), 50-60 m (dominated by bryozoans and bare rock) and 40-50 m plus all remaining strata between 60 and $90 \mathrm{~m}$ (dominated by bryozoans, black corals and sponges). However, the MDS plot indicated a clear distinction between samples from the UMZ and LMZ (Fig. 2b). 
Table 1 Reef fish species recorded on mesophotic reefs (30-90 m depth) of the St. Peter and St. Paul's Archipelago and their respective trophic groups

\begin{tabular}{|c|c|c|c|c|}
\hline Family & Species & $N$ & FO & Trophic group \\
\hline Pomacentridae & Chromis multilineata & 591 & 23 & Planktivore \\
\hline Balistidae & Melichthys niger & 495 & 28 & Omnivore \\
\hline Carangidae & Caranx lugubris & 398 & 20 & Piscivore \\
\hline Pomacentridae & Stegastes sanctipauli & 160 & 20 & Territorial herbivore \\
\hline Chaetodontidae & Prognathodes obliquus & 64 & 13 & Invertebrate feeder \\
\hline Pomacentridae & Abudefduf saxatilis & 61 & 14 & Omnivore \\
\hline Labridae & Bodianus insularis & 57 & 23 & Invertebrate feeder \\
\hline Balistidae & Canthidermis sufflamen & 41 & 9 & Planktivore \\
\hline Labridae & Halichoeres radiatus & 41 & 17 & Invertebrate feeder \\
\hline Holocentridae & Myripristis jacobus & 31 & 10 & Planktivore \\
\hline Pomacanthidae & Holacanthus ciliaris & 24 & 20 & Omnivore \\
\hline Pomacentridae & Chromis enchrysura & 20 & 15 & Planktivore \\
\hline Muraenidae & Muraena pavonina & 16 & 11 & Piscivore \\
\hline Pomacanthidae & Pomacanthus paru & 11 & 7 & Omnivore \\
\hline Chaetodontidae & Chaetodon striatus & 9 & 4 & Invertebrate feeder \\
\hline Aulostomidae & Aulostomus strigosus & 6 & 3 & Piscivore \\
\hline Serranidae & Rypticus saponaceus & 6 & 6 & Piscivore \\
\hline Labrisomidae & Malacoctenus sp. & 3 & 2 & Invertebrate feeder \\
\hline Blenniidae & Ophioblenius trinitatis & 1 & 1 & Territorial herbivore \\
\hline
\end{tabular}

$N$, total number of individuals recorded; FO, frequency of occurrence in samples. Species arranged according to abundance. Bold denotes species retained for quantitative analyses (see text)
Depth, turf algae, sponges, black corals, crustose calcareous algae and scleractinians were, in decreasing order (i.e., order of entrance in the model), the most important variables affecting the structure of fish assemblages. The first two axes explained $74 \%$ of the relationship between environmental characteristics and fish assemblage structure. There were unnoticeable differences in the structure of fish assemblages within the UMZ and a clear depth gradient from $50 \mathrm{~m}$ depth downwards (Fig. 5a). Nine species were associated with the UMZ, which was dominated by turf and crustose calcareous algae between 30 and $40 \mathrm{~m}$ and by scleractinian corals between 40 and $50 \mathrm{~m}$. Abudefduf saxatilis was associated with the 50-60 m depth stratum, which was characterized by low coral cover and intermediate values for all other independent variables. Chromis enchrysura was associated with the 60-70 m depth stratum and P. obliquus with reefs deeper than $70 \mathrm{~m}$, both of these latter species were clearly influenced by the abundance of black corals and sponges (Fig. 5a, b).

Abundance of black corals (total $n=141$ colonies) increased sharply with depth, with up to 15 colonies recorded per sample $\left(\sim 50 \mathrm{~m}^{2}\right)$ at depths $\geq 70 \mathrm{~m}$ (Fig. 6). Seven reef fish species were recorded seeking refuge within branches of black coral colonies: P. obliquus (37 individuals; $24.6 \%$ of total number of colonies occupied), juveniles of B. insularis $(12 ; 6.5 \%)$, C. enchrysura $(8 ; 6.5 \%)$, S. sanctipauli $(4 ; 3.3 \%)$, C. multilineata $(3 ; 2.4 \%)$ and Holacanthus ciliaris $(1 ; 0.8 \%)$.

\section{Discussion}

Assessments of mesophotic reefs of highly geographically isolated oceanic locations, such as the SPSPA, are still rare, due mainly to logistical challenges (Wagner et al. 2014; Magalhães et al. 2015; Meirelles et al. 2015). Euphotic reefs of the SPSPA are characterized by the lowest reef fish species richness among all tropical oceanic archipelagos ( $\sim 55$ species; Feitoza et al. 2003; Luiz et al. 2015). They are marked by the absence/rarity of snappers (Lutjanidae), groupers (Epinephelidae), surgeonfishes (Acanthuridae) and parrotfishes (Scarinae) (Feitoza et al. 2003; Luiz et al. 2015), all of them relatively common in the other three Brazilian oceanic islands (Rosa and Moura 1997; Krajewski and Floeter 2011; Pereira-Filho et al. 2011; Pinheiro et al. 2011) and along the Brazilian coast (e.g., Floeter et al. 2007; Francini-Filho and Moura 2008). Mesophotic reef fish assemblages of the SPSPA are even more depauperate, with only 19 species recorded in this study. In contrast, a total of 32 species were recorded in mesophotic reefs of the VTC (Meirelles et al. 2015; Pinheiro et al. 2015), while 28 species were recorded in the mesophotic zone of the Trindade Island, Brazil (Pereira-Filho et al. 2011; Pinheiro et al. 2015). The UMZ (30-50 m depth) of the SPSPA may be considered as an extension of the euphotic zone, as three species (C. multilineata, M. niger and S. sanctipauli) were among the four most abundant species in both zones (see Table 1 in Luiz et al. 2015; Table 1). The LMZ was 

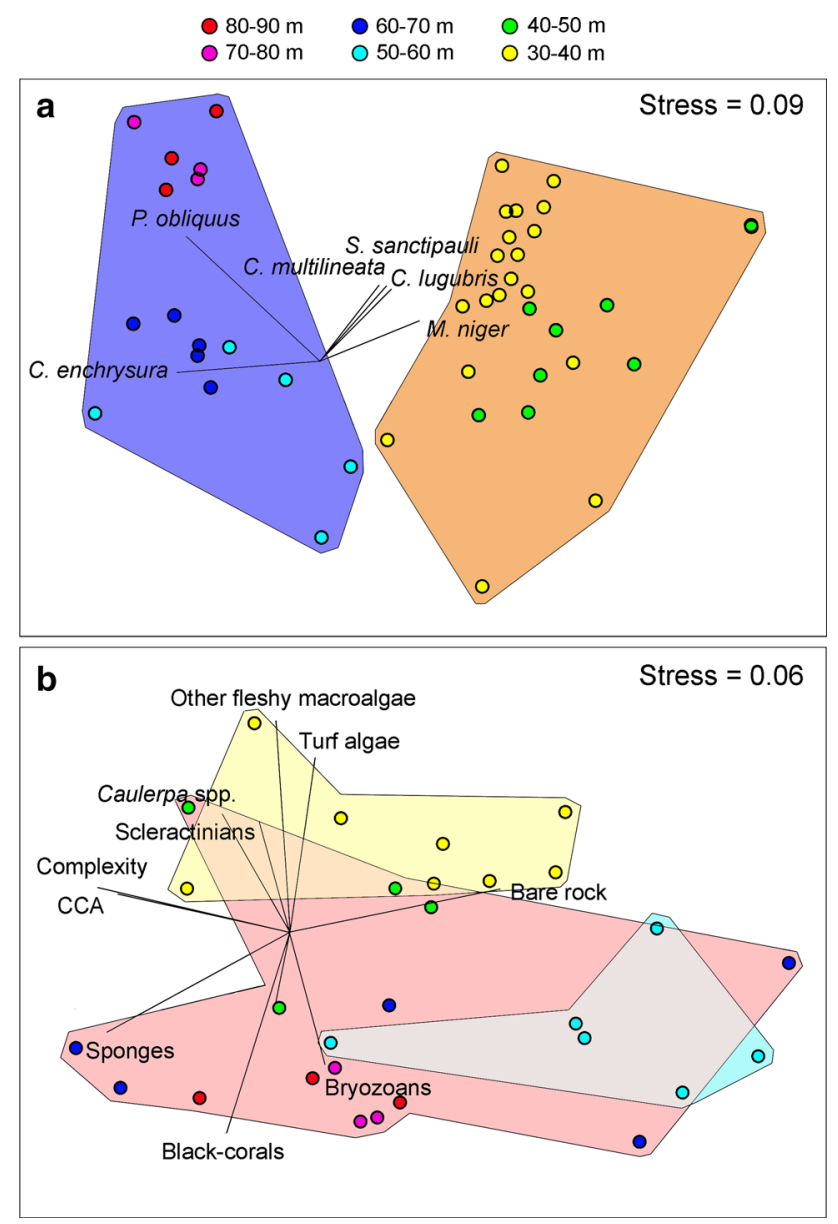

Fig. 2 Multidimensional scaling (MDS) of: a fish assemblages and b benthic assemblages, both based on Bray-Curtis similarities. Colored polygons indicate groups of samples with no significant differences $(p>0.05)$ as defined by analyses of similarities (ANOSIM). Colored dots indicate samples from different depth strata

dominated by $C$. enchrysura and P. obliquus, the former absent from euphotic reefs and the latter rarely sighted in the shallows (Luiz et al. 2015).

Depth was the most important variable influencing the structure of euphotic (Luiz et al. 2015) and mesophotic (this study) reef fish assemblages of the SPSPA. The influence of depth in reef fish assemblages is well known and may be explained by changes in light, water temperature, current regimes and food availability (e.g., McGehee 1994; Brokovich et al. 2008; Pereira-Filho et al. 2011; Fitzpatrick et al. 2012). Such changes may explain the sharp shift in the structure of fish assemblages at $50 \mathrm{~m}$ depth in the SPSPA, although more data are needed to formally test this hypothesis. Similarly, a unique and specialized reef community was identified in the lower mesophotic zone (60-100 m depth) of Curaçao, southern Caribbean (Bongaerts et al. 2015). Fish assemblages in the UMZ were influenced mainly by cover of turf algae, crustose calcareous algae and scleractinian corals, which may be explained by habitat preferences of the different species. For example, turf algae represent an important food source for M. niger and S. sanctipauli (Feitoza et al. 2003; Luiz et al. 2015).

Fish assemblages in the LMZ were influenced mainly by black corals and sponges. Colonies of black corals recorded here (Tanacetipathes spp.) were relatively large (up to $1.2 \mathrm{~m}$ in height) and with branching morphologies. The tridimensional habitat provided by black corals was clearly used as shelter by $C$. enchrysura, $P$. obliquus and juveniles of $B$. insularis. Prognathodes obliquus, which is endemic to the SPSPA, was also recorded grazing over black coral colonies [see Boland and Parrish (2005) for similar observations on Forcipiger flavissimus in Hawaii]. Reef fish species recorded within black corals in the mesophotic zone in Hawaii include Aulostomus chinensis, Canthigaster jactator, Centropyge potteri, Dascyllus albisella, Forcipiger flavissimus and Oxycirrhites typus, this latter considered a nearly obligate black coral dweller (Boland and Parrish 2005). These results highlight the key roles played by black corals in the mesophotic zone of the SPSPA and elsewhere.

The dominance of planktivores and low abundance of herbivores in mesophotic reefs of the SPSPA were expected, as similar patterns were recorded in previous studies focusing on MREs of other regions (e.g., Colin et al. 1986; Dennis and Bright 1988; Garcia-Sais 2010; Bryan et al. 2013; Bejarano et al. 2014). Greater abundances of herbivores in euphotic reefs dominated by photosynthetic algae are a widely recognized pattern (Choat 1991), and herbivores are indeed scarce at mesophotic habitats (Colin 1974; Brokovich et al. 2010; Kahng et al. 2010). The predominance of planktivores in mesophotic reefs may be explained by the fact that their food supply is not directly influenced by light and generally more abundant in the relatively cold waters of mesophotic depths. Garcia-Sais (2010) explained the high abundance of planktivores (particularly Chromis cyanea) in the upper limit of the mesophotic zone of Isla Desecheo, Puerto Rico, by the high availability of zooplankton arriving from the shelf edge. Variations in wind regime have been suggested to induce surfacing of the Equatorial Undercurrent in the SPSPA (Bowen 1966). During this study, abrupt drops in temperature of up to $5{ }^{\circ} \mathrm{C}$ were recorded in depths of 30-40 m. Therefore, high zooplankton availability coming from the colder Equatorial Undercurrent is a plausible explanation for the dominance of planktivores in mesophotic reefs of the SPSPA. Chromis multilineata was by far the most important species driving this pattern in depths up to $50 \mathrm{~m}$, while $C$. enchrysura was the most abundant planktivorous fish from $50 \mathrm{~m}$ down. In fact, the genus Chromis includes the few pomacentrid species known to 
Fig. 3 Relationship between abundance and depth for different fish species as defined by generalized additive models. a Abudefduf saxtilis; b Caranx lugubris; c Canthidermis sufflamen d Bodianus insularis; e Chromis enchrysura;

f Chromis multilineata;

g Halichoeres radiata;

h Holacanthus ciliaris:

i Melichthys niger; $\mathbf{j}$ Myripristis jacobus; k Prognathodes obliquus; I Stegastes sanctipauli. $95 \%$ confidence limits are shown in gray. ${ }^{*} p<0.05,{ }^{*} p<0.01$ $* * * p<0.001, \mathrm{~ns}-\mathrm{not}$ significant

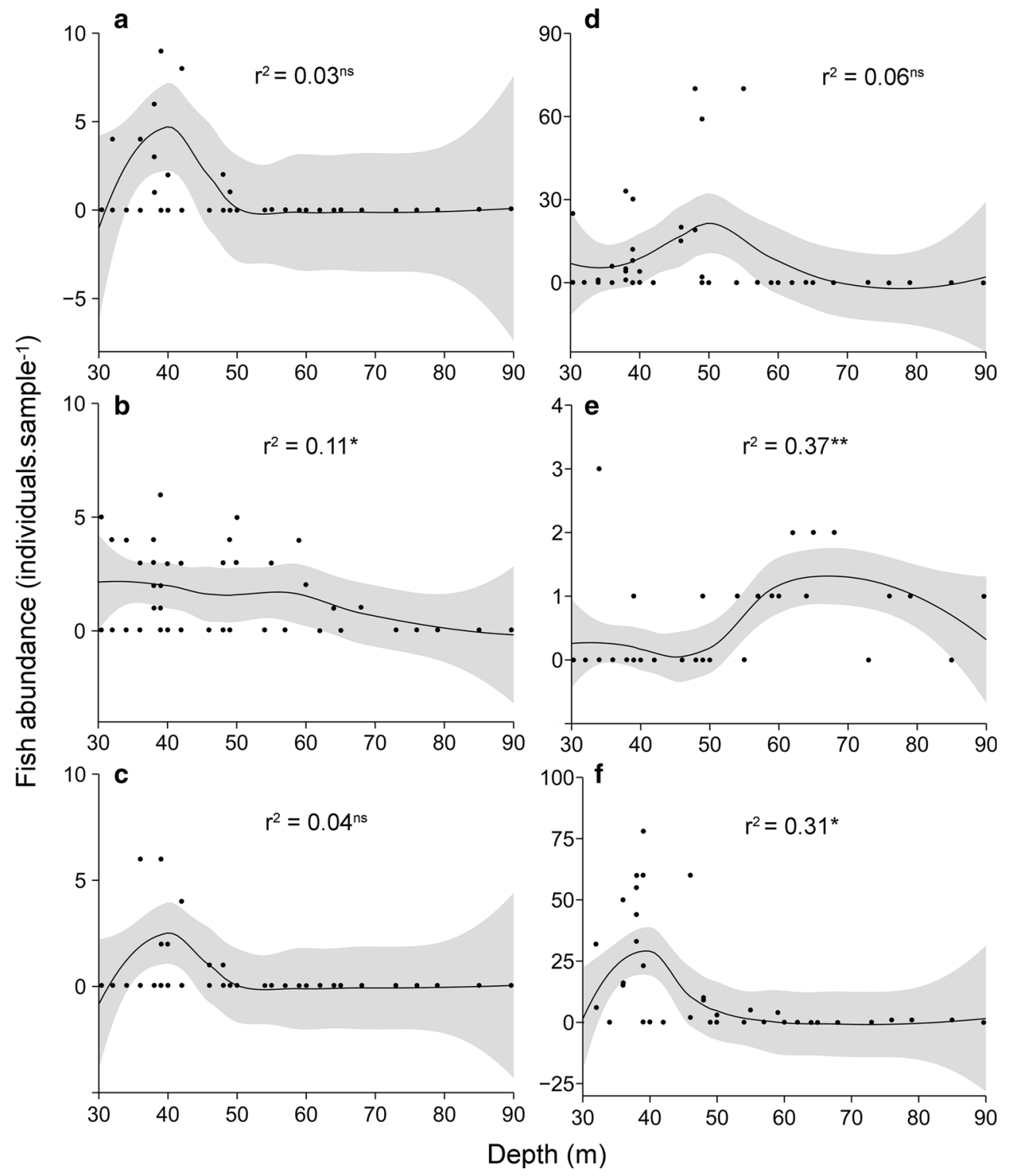

occur in mesophotic habitats, a pattern largely attributed to their diet based on zooplankton (Pyle et al. 2008).

Ontogenetic shifts in habitat use often occur in reef fish in ways to maximize foraging, reproduction and/or protection against predation (Dahlgren and Eggleston 2000). Ontogenetic trends along depth gradients have previously been recorded for reef fish, with juveniles generally concentrated at shallower depths (Colin 1974; Nagelkerken et al. 2000; Moura et al. 2011). However, there is growing evidence for the existence of mesophotic nurseries for some reef fish species (Brokovich et al. 2007). Twenty of the 57 individuals of $B$. insularis recorded here $(35.2 \%)$ were $<20 \mathrm{~cm} \mathrm{TL}$, all of them restricted to depths of $40-70 \mathrm{~m}$, while only individuals $>20 \mathrm{~cm}$ TL were sighted in the euphotic zone (authors' pers. obs.). Several species of Bodianus are recognized as having juveniles mostly or exclusively associated with mesophotic habitats (Lobel 1981; Randall and Chen 1985; Sazima et al. 2010). Mesophotic reefs were also recognized as important nurseries for Genicanthus caudovittatus (Pomacanthidae) in the Gulf of Aqaba, Red Sea (Brokovich et al. 2007), and for Clepticus parrae (Labridae) and Chromis insolata (Pomacentridae) in Isla Desecheo, Puerto Rico (Garcia-Sais 2010).

Mesophotic reefs are generally considered to be less susceptible to local and global disturbances, such as overfishing, pollution and climate change, than euphotic reefs. Thus, they may act as refuges and sources of propagules for shallow threatened reefs (the "deep reef refugia" hypothesis; Lesser et al. 2009; Bongaerts et al. 2010). The level of connectivity between euphotic and mesophotic zones (via larval dispersal or juvenile/adult 
Fig. 3 continued

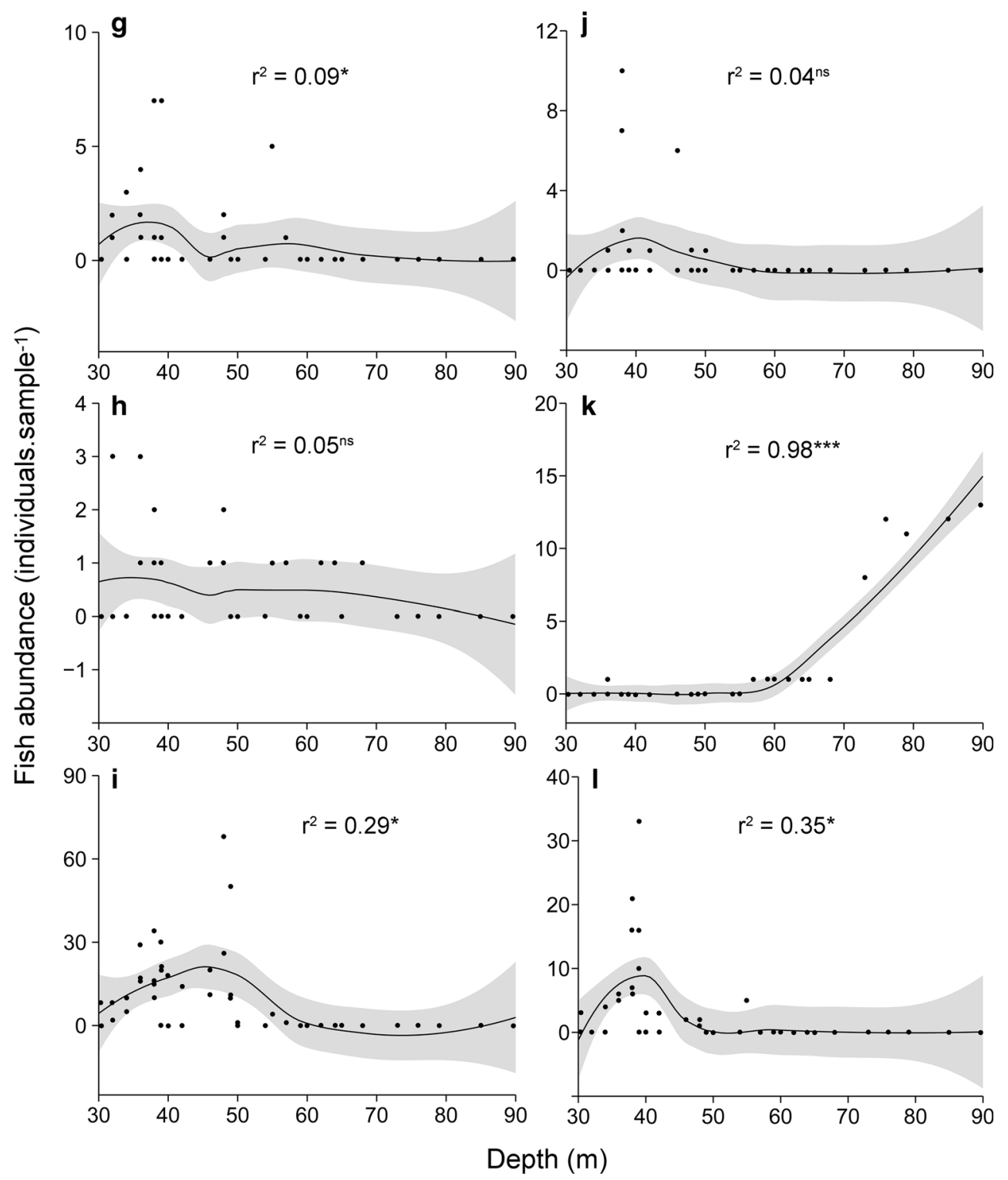

migration) is a central question regarding the mesophotic refuge hypothesis, with most benefits expected for species inhabiting both zones and with high levels of demographic/genetic connectivity (Slattery et al. 2011; Tenggardjaja et al. 2014; Papastamatiou et al. 2015). Data from this study, together with previously published data (Feitoza et al. 2003, Luiz et al. 2015), indicate that most reef fish species occurring in the SPSPA ( $>80 \%$ of all species) have a broad bathymetric distribution including both euphotic and mesophotic reefs. However, fish species nearly exclusively or exclusively associated with euphotic reefs, such as Ophioblennius trinitatis, Malacoctenus sp., Kyphosus spp. and Cantherhines macrocerus (Luiz et al. 2015), may be more susceptible to local extinction in the event of extreme events affecting euphotic reefs, such as storms and habitat degradation due to global changes (Fitzpatrick et al. 2012). However, it is important to note that the abundance of relatively small fishes such as O. trinitatis and Malacoctenus sp. may have been underestimated by the ROVs.

This study adds to the knowledge about Brazilian MREs (Feitoza et al. 2005; Pereira-Filho et al. 2011; Magalhães et al. 2015) and to the global database, as it includes novel information from a small and highly isolated site. Given the paucity of studies about MREs in the Atlantic and elsewhere, we hope that our data support future attempts for making broader generalizations about MREs (e.g., Lesser et al. 2009; Kahng et al. 2010, 2014) and serve as a baseline for future evaluations of possible anthropogenic and natural disturbances on MREs of the SPSPA. 


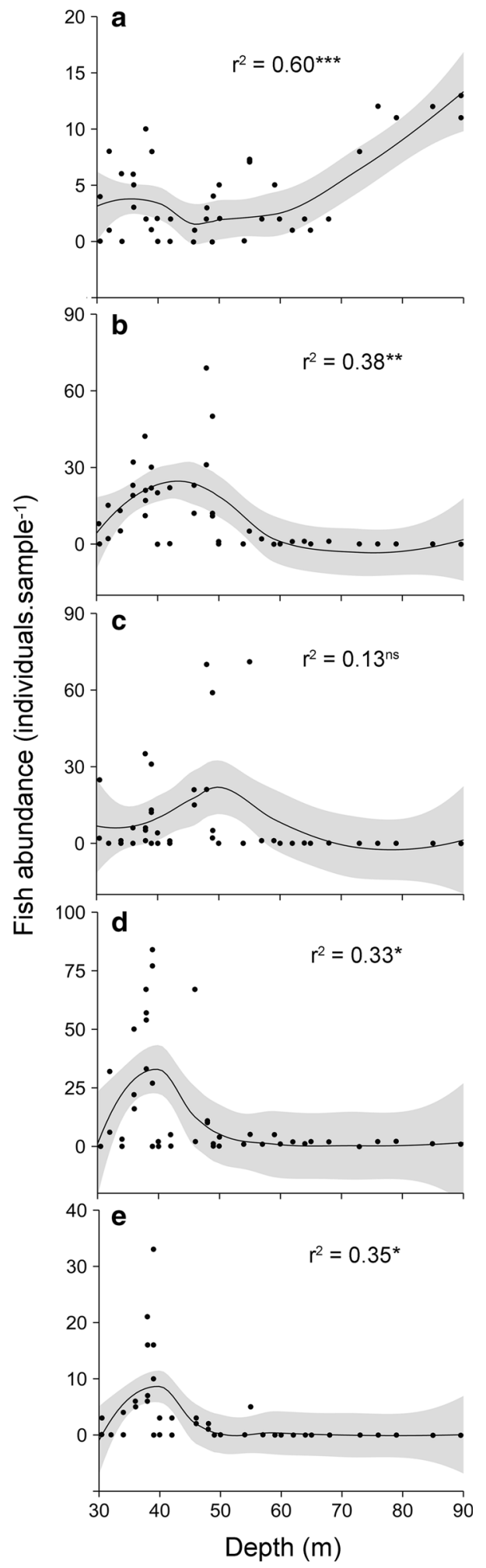

Fig. 4 Relationship between fish trophic groups and depth as defined by generalized additive models. $95 \%$ confidence limits are shown in gray. $* p<0.05, * * p<0.01, * * * p<0.001$, ns-not significant. Fish trophic groups: a invertebrate feeders, b omnivores, c piscivores, d planktivores and e territorial herbivores

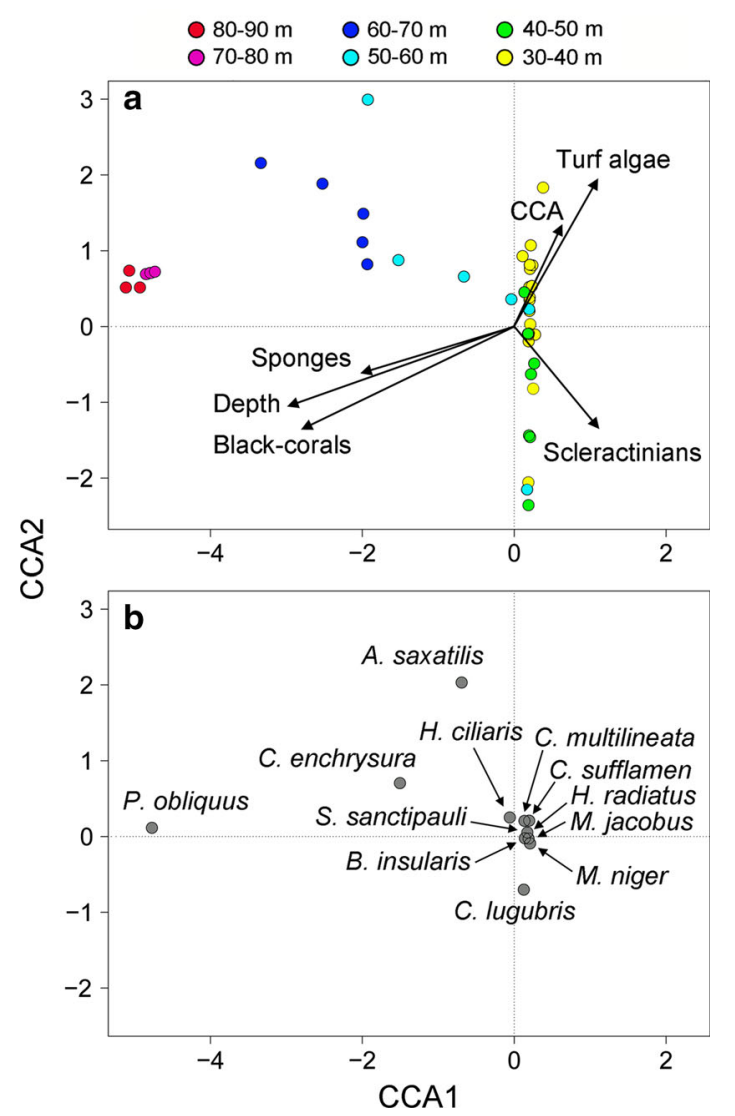

Fig. 5 Canonical correspondence analysis (CCA) plot showing: a relationship between independent variables (arrows) and samples from different depth strata (colored dots); and $\mathbf{b}$ distribution of fish species (gray dots) in the two-dimensional ordination space

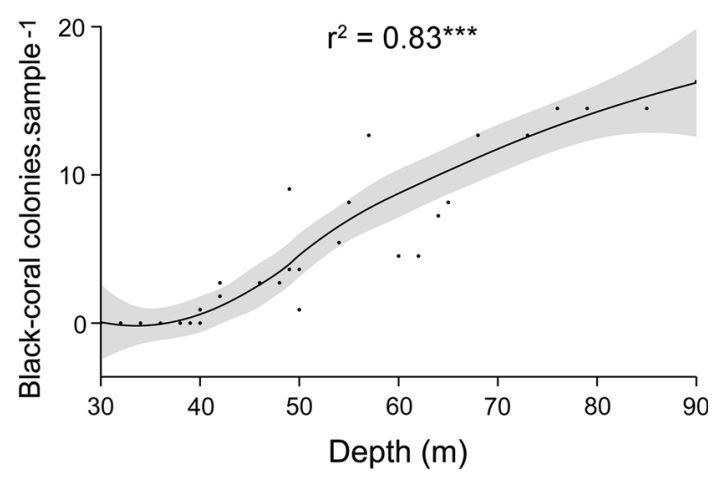

Fig. 6 Relationship between black coral abundance and depth as defined by generalized additive models. $95 \%$ confidence limits are shown in gray, $* * * p<0.001$

Acknowledgments We thank M. Villela, A.P.B. Moreira, L.S. Rodrigues and D. Sartor for field assistance and data collection; T. J. Mello for helping with data analyses; APA Fernando de Noronha/ Rocas/São Pedro e São Paulo/ICMBio for providing research permits; and the crew of Transmar I and Transmar III, as well as Secretaria de Comissão Interministerial para os Recursos do Mar (SECIRM) for 
logistical support. Financial support was provided by the Conselho Nacional de Desenvolvimento Científico e Tecnológico- $\mathrm{CNPq}$ (Grant 557185/09-2 to RBFF and 484875/2011-6 to GHPF). BPF, FLT, GMAF, PYGS, RBFF and RSR acknowledge individual grants from CNPq. GMAF, FLT and RLM acknowledge individual grants from Fundação de Amparo à Pesquisa do Estado do Rio de Janeiro (FAPERJ). MRR acknowledges a doctoral fellowship from Coordenação de Aperfeiçoamento de Pessoal de Nível Superior (CAPES).

\section{References}

Anderson WD, Heemstra PC (2012) Review of Atlantic and Eastern Pacific Anthiine fishes (Teleostei: Perciformes: Serranidae), with descriptions of two new genera. Trans Am Philos Soc 102:1-173

Bak RPM, Nieuwland G, Meesters EH (2005) Coral reef crisis in deep and shallow reefs: 30 years of constancy and change in reefs of Curacao and Bonaire. Coral Reefs 24:475-479

Bejarano IR, Appeldoorn S, Nemeth M (2014) Fishes associated with mesophotic coral ecosystems in La Parguera, Puerto Rico. Coral Reefs 33:313-328

Boland RC, Parrish FA (2005) A description of fish assemblages in the black coral beds off Lahaina, Maui, Hawai'i. Pac Sci 59:411-420

Bongaerts P, Ridgeway T, Sampayo EM, Hoegh-Guldberg O (2010) Assessing the 'deep reef refugia' hypothesis: focus on Caribbean reefs. Coral Reefs 29:309-327

Bongaerts P, Frade PR, Hay KB, Englebert N, Latijnhouwers KR, Bak RP, Vermeij MJA, Hoegh-Guldberg O (2015) Deep down on a Caribbean reef: lower mesophotic depths harbor a specialized coral-endosymbiont community. Sci Rep. doi:10. 1038/srep07652

Bowen VT (1966) St. Paul's on the subway. Oceanus 12:2-4

Brokovich E, Einbinder S, Kark S, Shashar N, Kiflawi M (2007) A deep nursery for juveniles of the zebra angelfish Genicanthus caudovittatus. Env Biol Fish 80:1-6

Brokovich E, Einbinder S, Shashar N, Kiflawi M, Kark S (2008) Descending to the twilight-zone: coral reef fish assemblages change along a depth gradient down to $65 \mathrm{~m}$. Mar Ecol Prog Ser 371:253-262

Brokovich E, Ayalon I, Einbinder S, Segev N, Shaked Y, Genin A, Kark S, Kiflawi M (2010) Grazing pressure on coral reefs decreases across a wide depth gradient in the Gulf of Aqaba, Red Sea. Mar Ecol Prog Ser 399:69-80

Bryan DR, Kilfoyle K, Gilmore RG, Spieler RE (2013) Characterization of the mesophotic reef fish community in south Florida, USA. J App Ichthyol 29:108-117

Choat JH (1991) The biology of herbivorous fishes on coral reefs. In: Sale PF (ed) The ecology of fishes on coral reefs. Academic Press, San Diego, pp 120-155

Clarke KR, Warwick RM (1994) Change in marine communities: an approach to statistical analysis and interpretation. Natural Environment Research Council, Plymouth

Colin PL (1974) Observation and collection of deep reef fishes off the coasts of Jamaica and Honduras. Mar Biol 24:29-38

Colin PL, Devaney DM, Hillis-Colinvaux L, Suchanek TH, Harrison JT (1986) Geology and biological zonation of the reef slope, 50-360 m depth at Enewetak Atoll, Marshall Islands. Bull Mar Sci 38:111-128

Dahlgren CP, Eggleston DB (2000) Ecological processes underlying ontogenetic habitat shifts in a coral reef fish. Ecology 81:2227-2240

Dennis GD, Bright TJ (1988) Reef fish assemblages on hard banks in the northwest Gulf of Mexico. Bull Mar Sci 43:280-307
Edwards A, Lubbock R (1983a) Marine zoogeography of St. Paul's Rocks. J Biogeogr 10:65-72

Edwards A, Lubbock R (1983b) The ecology of Saint Paul's Rocks (Equatorial Atlantic). J Zool 200:51-69

Feitoza BM, Rocha LA, Luiz OJ, Floeter SR, Gasparini JL (2003) Reef fishes of St. Paul's Rocks: new records and notes on biology and zoogeography. Aqua 7:61-82

Feitoza BM, Rosa RS, Rocha LA (2005) Ecology and zoogeography of deep-reef fishes in northeastern Brazil. Bull Mar Sci 76:725-742

Ferreira CEL, Luiz OJ, Feitoza B, Ferreira CGW, Gasparini JL, Noguchi RC, Godoy EA, Joyeux JC, Rangel CA, Rocha LA, Floeter SR, Carvalho-Filho A (2009) Peixes recifais: síntese do atual conhecimento. In: Viana DL, Hazin FHV, Souza MAC (eds) O Arquipélago de São Pedro e São Paulo: 10 anos de estação científica. SECIRM, Brasília, pp 244-340

Fitzpatrick BM, Harvey ES, Heyward AJ, Twiggs EJ, Colquhoun J (2012) Habitat specialization in tropical continental shelf demersal fish assemblages. PLoS One 7:e39634

Floeter SR, Gasparini JL (2000) The southwestern Atlantic reef-fish fauna: composition and zoogeographic patterns. J Fish Biol 56:1099-1114

Floeter SR, Krohling W, Gasparini JL, Ferreira CE, Zalmon IR (2007) Reef fish community structure on coastal islands of the southeastern Brazil: the influence of exposure and benthic cover. Env Biol Fish 78:147-160

Floeter SR, Rocha LA, Robertson DR, Joyeux JC, Smith-Vaniz WF, Wirtz P, Edwards AJ, Barreiros JP, Ferreira CEL, Gasparini JL, Brito A, Falcón JM, Bowen BW, Bernardi G (2008) Atlantic reef fish biogeography and evolution. J Biogeogr 35:22-47

Francini-Filho RB, Moura RL (2008) Dynamics of fish assemblages on coral reefs subjected to different management regimes in the Abrolhos Bank, eastern Brazil. Aquat Conserv 18:1166-1179

Garcia-Sais JR (2010) Reef habitats and associated sessile-benthic and fish assemblages across a euphotic-mesophotic depth gradient in Isla Desecheo, Puerto Rico. Coral Reefs 29:277-288

Harris PT, Bridge TCL, Beaman RJ, Webster JM, Nichol SL, Brooke BP (2013) Submerged banks in the Great Barrier Reef, Australia, greatly increase available coral reef habitat. ICES J Mar Sci 70:284-293

Hastie TJ, Tibshirani RJ (1990). Generalized additive models. Monographs on Statistics and Applied Probability, vol. 43. CRC Press, Boca Ratan, FL

Hazin FHV, Viana D, Pinheiro P, Fischer A, Macena B, Véras D, Oliveira P, Carvalho F, Vaske-Jr T, Branco I (2009) Ecologia de grandes peixes pelágicos. In: Viana DL, Hazin FHV, Souza MAC (eds) O Arquipélago de São Pedro e São Paulo: 10 anos de estação científica. SECIRM, Brasília, pp 226-233

Hinderstein LM, Marr JCA, Martinez FA, Dowgiallo MJ, Puglise KA, Pyle RL, Zawada DG, Appeldoorn R (2010) Introduction to mesophotic coral ecosystems: characterization, ecology, and management. Coral Reefs 29:247-251

Kahng SE, Spalding HL, Brokovich E, Wagner D, Weil E, Hinderstein L, Toonen RJ (2010) Community ecology of mesophotic coral reef ecosystems. Coral Reefs 29:255-275

Kahng SE, Copus JM, Wagner D (2014) Recent advances in the ecology of mesophotic coral ecosystems (MCEs). Curr Opin Environ Sustain 7:72-81

Kane C, Kosaki RK, Wagner D (2014) High levels of mesophotic reef fish endemism in the northwestern Hawaiian Islands. Bull Mar Sci 90:693-703

Kohler KE, Gill SM (2006) Coral Point Count with Excel extensions (CPCe): a visual basic program for the determination of coral and substrate coverage using random point count methodology. Comput Geosci 32:1259-1269 
Krajewski JP, Floeter SR (2011) Reef fish community structure of the Fernando de Noronha Archipelago (Equatorial Western Atlantic): the influence of exposure and benthic composition. Environ Biol Fish 92:25-40

Lesser MP, Slattery M (2011) Invasive lionfish causes a phase shift to algal dominated communities at mesophotic depths on a Bahamian coral reef. Biol Invasions 13:1855-1868

Lesser MP, Slattery M, Leichter JJ (2009) Ecology of mesophotic coral reefs. J Exp Mar Biol Ecol 375:1-8

Lobel PS (1981) Bodianus prognathus (Labridae, Pisces), a new longnose hogfish from the Central Pacific. Pac Sci 35:45-50

Longo GO, Morais RA, Martins CDL, Mendes TC, Aued AW, Cândido DV, Oliveira JC, Nunes LT, Fontoura L, Sissini MN, Teschima MM, Silva MB, Ramlov F, Gouvea LP, Ferreira CEL, Segal B, Horta PA, Floeter SR (2015) Between-habitat variation of benthic cover, reef fish assemblage and feeding pressure on the benthos at the only atoll in South Atlantic: Rocas Atoll, NE Brazil. PloS One 10:e0127176

Lubbock R, Edwards A (1981) The fishes of Saint Paul's rocks. J Fish Biol 18:135-157

Luiz O, Edwards AL (2011) Extinction of a shark population in the Archipelago of Saint Paul's Rocks (equatorial Atlantic) inferred from the historical record. Biol Conserv 144:2873-2881

Luiz O, Mendes T, Barneche D, Ferreira C, Noguchi R, Villaca R, Rangel CA, Gasparini JL, Ferreira CEL (2015) Community structure of reef fishes on a remote oceanic island (St. Peter and St. Paul's Archipelago, equatorial Atlantic): the relative influence of abiotic and biotic variables. Mar Freshw Res [doi: 10. 1071/MF14150]

Magalhães GM, Amado-Filho GM, Rosa MR, Moura RL, Brasileiro PS, Moraes FC, Francini-Filho RB, Pereira-Filho GH (2015) Changes in benthic communities along a 0-60 m depth gradient in the remote St. Peter and St. Paul Archipelago (Mid-Atlantic Ridge, Brazil). Bull Mar Sci [doi: 10.5343/bms.2014.1044]

Meirelles PM, Amado-Filho GM, Pereira-Filho GH, Pinheiro HT, Moura RL, Joyeux JC, Mazzei EF, Bastos AC, Edwards RA, Dinsdale E, Paranhos R, Santos EO, Iida T, Gotoh K, Nakamura S, Sawabe T, Rezende CE, Gadelha LMR Jr, Francini-Filho RB, Thompson C, Thompson FL (2015) Baseline assessment of mesophotic reefs of the Vitória-Trindade seamount chain based on water quality, microbial diversity, benthic cover and fish biomass data. PloS One 10:e130084

McGehee MA (1994) Correspondence between assemblages of coral reef fishes and gradients of water motion, depth, and substrate size off Puerto Rico. Mar Ecol Prog Ser 105:243-255

Menza C, Kendall M, Rogers C, Miller J (2007) A deep reef in deep trouble. Cont Shelf Res 27:2224-2230

Minte-Vera CV, Moura RL, Francini-Filho RB (2008) Nested sampling: an improved visual-census technique for studying reef fish assemblages. Mar Ecol Prog Ser 367:283-293

Moura RL, Francini-Filho RB, Chaves EM, Minte-Vera CV, Lindeman K (2011) Use of riverine through reef habitat systems by dog snapper (Lutjanus jocu) in eastern Brazil. Estuar Coast Shelf Sci 95:274-278

Nagelkerken I, van der Velde G, Gorissen MW, Meijer GJ, van't Hof T, den Hartog C (2000) Importance of mangroves, seagrass beds, and the shallow coral reef as a nursery for important coral reef fishes, using a visual census technique. Estuar Coast Shelf Sci 51:31-44

Papastamatiou YP, Meyer CG, Kosaki RK, Wallsgrove NJ, Popp BN (2015) Movements and foraging of predators associated with mesophotic coral reefs and their potential for linking ecological habitats. Mar Ecol Prog Ser 521:155-170

Pereira-Filho GH, Amado-Filho GM, Guimarães SMPB, Moura RL, Sumida PYG, Abrantes DP, Bahia RG, Guth AZ, Jorge RR, Francini-Filho RB (2011) Reef fish and benthic assemblages of the Trindade and Martin Vaz island group, southwestern Atlantic. Braz J Oceanogr 59:201-212

Pinheiro HT, Ferreira CEL, Joyeux JC, Santos RG, Horta PA (2011) Reef fish structure and distribution in a south-western Atlantic Ocean tropical island. J Fish Biol 79:1984-2006

Pinheiro HT, Mazzei E, Moura RL, Amado-Filho GM, CarvalhoFilho A, Braga AC, Costa PAS, Ferreira BP, Ferreira CEL, Floeter SR, Francini-Filho RB, Gasparini JL, Macieira RM, Martins AS, Olavo G, Pimentel CR, Rocha LA, Sazima I, Simon T, Teixeira JB, Xavier LB, Joyeux JC (2015) Fish biodiversity of the Vitória-Trindade Seamount Chain, southwestern Atlantic: an updated database. PloS One 10:e0118180

Pyle RL, Early JL, Greene BD (2008) Five new species of the damselfish genus Chromis (Perciformes: Labroidei: Pomacentridae) from deep coral reefs in the tropical western Pacific. Zootaxa 1671:3-31

R Core Team (2014) R: A language and environment for statistical computing. R Foundation for Statistical Computing, Vienna, Austria

Randall RE, Chen C (1985) First record of the labrid fish Bodianus cylindriatus (Tanaka) from the Hawaiian Islands. Pac Sci 39:291-293

Rocha LA (2003) Patterns of distribution and processes of speciation in Brazilian reef fishes. J Biogeogr 30:1161-1171

Rosa RS, Moura RL (1997) Visual assessment of reef fish community structure in the Atol das Rocas Biological Reserve, off northeastern Brazil. Proc 8th Int Coral Reef Symp 1:983-986

Sazima I, Grossman A, Sazima C (2010) Deep cleaning: a wrasse and a goby clean reef fish below $60 \mathrm{~m}$ depth in the tropical southwestern Atlantic. Mar Biodivers Rec 3:60-63

Slattery M, Lesser MP, Brazeau D, Stokes MD, Leichter JJ (2011) Connectivity and stability of mesophotic coral reefs. J Exp Mar Biol Ecol 408:32-41

Swartzman G, Huang C, Kaluzny S (1992) Spatial analysis of Bering Sea groundfish survey data using generalized additive models. Can J Fish Aquat Sci 49:1366-1378

Tenggardjaja KA, Bowen BW, Bernardi G (2014) Vertical and horizontal genetic connectivity in Chromis verater, an endemic damselfish found on shallow and mesophotic reefs in the Hawaiian Archipelago and adjacent Johnston Atoll. PloS One 9:e115493

ter Braak CJF (1996) Unimodal methods to relate species to environment. Centre for Biometry Wageningen (DLO Agricultural Mathematics Group), Wageningen, The Netherlands

Vaske-Jr T, Lessa RPT, Ribeiro ACB, Nóbrega MF, Pereira AA, Andrade CDP (2006) A pesca comercial de peixes pelágicos no arquipélago de São Pedro e São Paulo, Brasil. Trop Oceanogr 34:31-41

Wagner D, Kosaki RK, Spalding HL, Whitton RK, Pyle RL, Sherwood AR, Tsuda RT, Calcinai B (2014) Mesophotic surveys of the flora and fauna at Johnston Atoll, Central Pacific Ocean. Mar Biodivers Rec 7:e68

Wilson SK, Graham NAJ, Polunin NVC (2007) Appraisal of visual assessments of habitat complexity and benthic composition on coral reefs. Mar Biol 151:1069-1076 